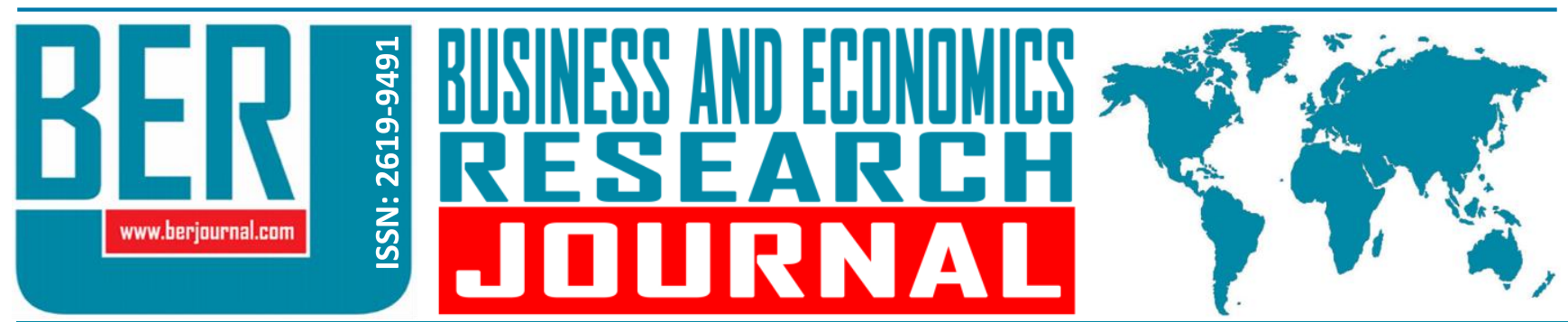

Business and Economics Research Journal Vol. 11, No. 2, 2020, pp. 371-384 doi: 10.20409/berj.2020.255

\title{
Farklı Risk Türleri ve Borsa Endeksi Arasındaki İlişki: Türkiye İçin Nedensellik Testleri
}

\author{
Yuksel Iltas $^{\mathrm{a}}$
}

Öz: Bu çalışma, ekonomik, politik, finansal ve jeopolitik ülke riskleri ile hisse senedi fiyatları arasındaki ilişkiyi Türkiye örneğinde 1999:01-2014:12 döneminde incelemektedir. Risk primleri ile BIST 100 endeksi arasındaki nedensellik ilişkisi Toda-Yamamoto nedensellik testi ve Hacker-Hatemi-J (2012) bootstrap nedensellik testi ile analiz edilmiştir. Toda-Yamamoto nedensellik testi sonuçlarına göre ekonomik risk primi ve politik risk primi ile BisT100 Endeksi arasında çift yönlü nedensellik ilişkisi tespit edilirken finansal risk primi ve jeopolitik risk primi için BisT100 Endeksine doğru nedensellik saptanamamıştır. Hacker ve Hatemi-J (2012) bootstrap nedensellik testi sonuçlarına göre ekonomik risk primi ve politik risk primi ile BiST100 Endeksi arasında çift yönlü nedensellik ilişkisi tespit edilirken; finansal risk pirimi ve jeopolitik risk pirimi ile BIST100 Endeksi arasında nedensellik ilişkisi tespit edilememiştir. Hacker ve Hatemi-J (2012) bootstrap nedensellik testi sonuçları da Toda-Yamamoto nedensellik testi sonuçlarını doğrulamaktadır. Çalışmada uygulanan nedensellik testleri, makroekonomik değişkenlere dayalı ekonomik risk primi ve ülkenin siyasi yapısını gösteren politik risk primi ile hisse senedi fiyatları arasında çift yönlü nedensellik ilişkisinin olduğunu göstermektedir.

\section{The Relationship between Different Types of Risk and Stock Market Index: Causality Tests for Turkey}

\begin{abstract}
This paper examines the relationship between economic, political, financial and geopolitical country risks and stock prices for the case of Turkey during the period 1999: 012014: 12. The causal relationship between risk premiums and BIST 100 index is analyzed through Toda-Yamamoto and Hacker and Hatemi-J (2012) causality tests. According to Toda-Yamamoto causality test's results, while there is bidirectional causality between economic risk premium and BIST 100 index and between political risk premium and BIST 100 Index, there is no causality from financial risk premium and geopolitical risk premium to BIST 100 Index. According to the result of Hacker and Hatemi-J (2012) bootstrap causality test, while there is bi-directional causality between economic risk premium and BIST 100 index and between political risk premium and BIST 100 Index, there is no causality between financial risk premium and BIST 100 index and between geopolitical risk premium and BIST 100 Index. The results of Hacker and Hatemi-J (2012) bootstrap causality test confirm the results of the Toda-Yamamoto causality test. Causality tests performed in the study indicate the existence of bidirectional causality relationship among economic risk premium based on macroeconomic variables and political risk premium as an indicator of the country's political environment, and stock prices.
\end{abstract}

\author{
Anahtar Sözcükler: \\ Ekonomik Risk, Politik Risk, \\ Finansal Risk, Hisse Senedi \\ Fiyatları, BiST100, \\ Nedensellik Testleri
}

JEL: G00, G30, G32

$\begin{array}{ll}\text { Geliş } & : 20 \text { Ocak } 2020 \\ \begin{array}{l}\text { Düzeltme } \\ \text { Kabul }\end{array} & : 04 \text { Mart } 2020 \\ & : 18 \text { Mart 2020 } \\ \text { Tür } & : \text { Araştırma }\end{array}$

Keywords: Economic Risk Political Risk, Financial Risk, Stock Prices, BIST100, Causality Tests

JEL: G00, G30, G32

$\begin{array}{ll}\text { Received } & : 20 \text { January } 2020 \\ \text { Revised } & : 04 \text { March } 2020 \\ \text { Accepted } & : 18 \text { March } 2020 \\ & \\ \text { Type } & \text { : Research }\end{array}$

Cite this article as: Iltas, Y. (2020). Farklı risk türleri ve borsa endeksi arasındaki ilişki: Türkiye için nedensellik testleri. Business and Economics Research Journal, 11(2), 371-384.

The current issue and archive of this Journal is available at: www.berjournal.com 


\section{Giriş}

Gerek işletmeler gerekse bireysel ve kurumsal yatırımcılar getiri elde etmek ve birikimlerini artırmak için sahip oldukları fonları optimum şekilde değerlendirmeyi istemektedirler. Ancak yatırım yapılan ekonomik veya finansal alanlara özgü sistematik ve sistematik olmayan riskler fonların optimum kullanımına engel oluşturabilmektedir.

İstikrarlı ve işleyen bir ekonomide performansın en önemli belirleyicilerinden biri finansal sistem ile ekonominin tümü arasındaki ilişkidir. Finansal sistemin işleyişi fon fazlalarının fon talep edenlere optimal şekilde, en düşük maliyetle ve en etkin şekilde transferini gerçekleştirerek ekonominin düzenli ve verimli çalışmasını sağlar (Coşkun vd., 2012: 1).

Piyasa sistemine dayalı ekonomilerde menkul kıymet borsaları en önemli finansal aracı kurumlardan biri olup, aracılık fonksiyonlarının yanı sıra birçok ekonomik işlevi de bulunmaktadır. Ekonomik, sosyal ve politik hayattaki değişmeler, gelişmeler ve problemler derhal menkul kıymet borsalarına yansımaktadır (Karan, 2004: 45). Menkul kıymet borsaları ilk önce ekonomilerin gidişatı konusunda barometre işlevi görmekte, ekonomik birimlere sinyaller göndererek yön göstermektedir.

Menkul kıymet borsaları, finansal varlıkların en kısa sürede nakit paraya çevrilebildiği piyasalardır. Borsalar, çok sayıda alıcı ve satıcıyı bir araya getirerek taraflarca genel kabul görecek tek fiyatın oluşmasına katkı sağlarken aynı zamanda da işletmelere devamlı ve uzun vadeli kaynak ve likidite sağlama görevini de üstlenmektedir.

Hisse senedi arz ve talebinin buluştuğu bir pazar olan hisse senedi piyasaları yalnızca hisse senedi alım-satım kararlarının verildiği pazarlar değil, aynı zamanda fonların toplandığı, risklerin dağıtıldığı ve servetin aktarıldığı ortamlardır. Özellikle ekonomik ve finansal istikrarı kırılgan yapıda olan ülkelerde, tasarruf sahiplerinin büyük çoğunluğu tasarruflarını uzun vadeli yatırımlara dönüştürmekte tereddüt etmektedirler. Ancak borsaların yarattığı likidite imkânı, tek ve güvenli fiyat oluşumu, işletmelerin bu yolla uzun vadeli borçlanma senedi ihracı yoluyla kaynak sağlamasını kolaylaştırmaktadır. Bu durumda borsaların işletmelerin uzun vadeli yatırımlarını kısa vadeli tasarruflar ile gerçekleştirebilmelerine imkân sağladığı kabul edilebilir.

Menkul kıymetlere yatırım kararının temel belirleyicileri getiri ve risk faktörleridir (Kaya, Güngör ve Özçomak, 2014: 75). Risk geleceğe ait olup gelecekteki beklentilerle ilgili hesaplamaları içermektedir. Portföy kuramında yatıım ının riski kontrol altına alabilme veya sınırlayabilme olanağının olup olmamasına göre, toplam risk; sistematik ve sistematik olmayan risk olarak iki ana gruba ayrılabilir (Ceylan ve Korkmaz, 2015: 575). Sistematik olmayan risk, finansal sistemin tamamını değil gerçekleştiğinde daha çok igili firma veya sektörü etkileyen riskleri ifade etmektedir. Sistematik olmayan riskler portföy çeşitlendirmesiyle yok edilebilen risklerdir (Ercan ve Ban, 2005: 179). Sistematik risk ise ekonomik, politik, finansal ve benzeri çevresel faktörlerin değişkenliğinden kaynaklanan ve bütün ekonomik birimleri aynı yönde fakat değişik derecede etkileyen önemli bir risk çeşididir. Sistematik riskler, yatırım aracı sayısının artırılıp azaltılması veya çeşitlendirilmesi ile azaltılamamakta ya da ortadan kaldıılamamaktadır (Yapraklı ve Güngör, 2007: 200).

Birçok uygulamalı çalışmada tercih edilen ve güvenirliği kabul edilmiş olan Uluslararası Ülke Riski Rehberi (International Country Risk Guide-ICRG) 1980 yılında International Report Dergisi editörleri tarafından geliştirilmiştir (Tükenmez ve Kutay, 2016: 635). ICRG 1980 yılından itibaren yaklaşık 140 ülkenin politik, finansal ve ekonomik açıdan risk endekslerini belirleyebilmek için düzenli olarak aylık veri toplayan bir kuruluştur. ICRG'de ülke riski; ekonomik risk, politik risk ve finansal risk olmak üzere üç temel bileşenden oluşmakta ve toplam 22 değişkenle açıklanmaktadır. ICRG veri setinde ekonomik risk 5 alt bileşenden; politik risk 12 alt bileşenden ve finansal risk ise 5 alt bileşenden oluşmaktadır (Kaya vd., 2014: 78). Ekonomik riskin alt bileşenlerini kişi başına GSYiH, reel GSYiH'daki yıllık büyüme, enflasyon oranı, bütçe dengesi/GSYiH ve cari denge/GSYiH gibi makroekonomik değişkenler oluşturmaktadır. Politik riskin alt bileşenlerini hükümet istikrarı, sosyoekonomik durum, yatırım profili, içsel çatışmalar, dışsal çatışmalar, yolsuzluk, politik alanda askerin etkisi, politik alanda dinin etkisi, kanun ve düzen, etnik gerilimler, demokratik hesap verebilirlik ve bürokratik kalite oluşturmaktadır. Finansal riskin alt bileşenlerini ise dış borcun GSYiH'ya oranı, dış borç 
servisi/ihracat, mal ve hizmet ihracatının bir yüzdesi olan cari hesap, ithalata ödenen net uluslararası likidite ve döviz kuru istikrarı gibi makro değişkenler oluşturmaktadır (www.prsgroup.com).

Menkul kıymet piyasalarında yatırımcıların yatırım kararı almalarında en önemli değişkenlerden birisi hisse senedi fiyatlarıdır. Ülkedeki orta ve uzun vadeli fon arz edenlerle fon talep edenleri bir araya getiren sermaye piyasaları bazı dönemlerde ekonomik gelişmelere karşı aşırı tepki verebilmektedir. Hisse senetleri de riskli yatıım araçları oldukları için ekonomik gelişmelere oldukça hızlı tepki vermektedir. Ancak ekonomik faktörler her zaman hisse senedi fiyatları ile aynı yönde hareket etmeyebilir. Bu durumda da hisse senetleri her zaman ekonomik faktörleri fiyatlayamaz ve ekonomik faktörlerin hisse senedi fiyatı üzerindeki etkilerini ölçmek zorlaşmaktadır (Albeni ve Demir, 2005: 3).

Tablo 1'de Türkiye Sermaye Piyasaları Birliği tarafından yıllık olarak yayınlanan Türkiye Sermaye Piyasası Raporunun finansal piyasalar kısmından BIST'e ilişkin derlenen veriler yer almaktadır.

Tablo 1. Borsa İstanbul'a Ait Piyasa Verileri

\begin{tabular}{|c|c|c|c|c|c|c|c|c|c|c|c|c|}
\hline \multirow{2}{*}{$\begin{array}{l}\text { Piyasa } \\
\text { Verisi }\end{array}$} & \multicolumn{2}{|c|}{$\begin{array}{l}\text { Endeks Getirisi } \\
\text { (ABD \$ Bazlı) }\end{array}$} & \multicolumn{2}{|c|}{$\begin{array}{l}\text { Piyasa Değeri } \\
\text { (Milyar \$) }\end{array}$} & \multicolumn{2}{|c|}{$\begin{array}{c}\text { Piyasa Değeri } \\
\text { Payı }\end{array}$} & \multicolumn{2}{|c|}{$\begin{array}{c}\text { Piyasa } \\
\text { Değeri/ } \\
\text { GSYH }\end{array}$} & \multicolumn{2}{|c|}{$\begin{array}{c}\text { İşlem } \\
\text { Hacmi } \\
\text { (milyar \$) }\end{array}$} & \multicolumn{2}{|c|}{$\begin{array}{c}\text { Hacim/Piyasa } \\
\text { Değeri }\end{array}$} \\
\hline & Sira & Değer & Sira & Değer & Sira & Değer & Sıra & Değer & Sira & Değer & Sira & Değer \\
\hline 2017 & 9 & $\% 37,7$ & 32 & 228 & 32 & $\% 0,3$ & 32 & $\% 26,7$ & 22 & 395 & 4 & $\% 173,8$ \\
\hline 2016 & 68 & $-\% 10,0$ & 32 & 158 & 32 & $\% 0,2$ & 32 & $\% 20,0$ & 22 & 331 & 3 & $\% 420,0$ \\
\hline 2015 & 77 & $-\% 33,0$ & 32 & 189 & 32 & $\% 0,4$ & 32 & $\% 25,4$ & 23 & 351 & 6 & $\% 216,8$ \\
\hline 2014 & 13 & $\% 15,8$ & 30 & 220 & 30 & $\% 0,3$ & 30 & $\% 27,0$ & 20 & 370 & 4 & $\% 168,3$ \\
\hline 2013 & 54 & $-\% 28,0$ & 36 & 196 & 36 & $\% 0,3$ & 36 & $\% 24,0$ & 21 & 375 & 3 & $\% 191,0$ \\
\hline 2012 & 1 & $\% 61,4$ & 28 & 311 & 28 & $\% 0,6$ & 28 & $\% 40,0$ & 20 & 349 & 6 & $\% 112,0$ \\
\hline 2011 & 44 & $-\% 36,7$ & 32 & 201 & 32 & $\% 0,4$ & 32 & $\% 26,0$ & 20 & 424 & 3 & $\% 210,0$ \\
\hline 2010 & 17 & $\% 21,0$ & 28 & 308 & 28 & $\% 0,6$ & 28 & $\% 42,0$ & 19 & 426 & 5 & $\% 138,0$ \\
\hline 2009 & 6 & $\% 102,0$ & 25 & 236 & 25 & $\% 0,5$ & 25 & $\% 38,0$ & 21 & 316 & 7 & $\% 134,0$ \\
\hline 2008 & 49 & $-\% 63,0$ & 30 & 120 & 30 & $\% 0,4$ & 30 & $\% 16,0$ & 25 & 261 & 6 & $\% 218,0$ \\
\hline 2007 & 2 & $\% 72,0$ & 26 & 290 & 26 & $\% 0,5$ & 26 & $\% 44,0$ & 25 & 301 & 10 & $\% 103,7$ \\
\hline
\end{tabular}

Kaynak: Yazar tarafından Türkiye Sermaye Piyasası raporlarından oluşturulmuştur.

Tablo 1 incelendiğinde, BiST'in \$ bazlı getirisinin dalgalı bir seyir izlediği görülmektedir. BiST'in piyasa değeri dünya borsaları sıralamasında 25 ile 32. sıra arasında yer almaktadır. Iş̧lem hacmi ise ortalama olarak 355 milyar \$ düzeyinde gerçekleşmiştir. Tablo 1'de dikkat çeken nokta hisse senedi devir hızı olarak adlandırılan hisse senedi işlem hacminin toplam piyasa değerine oranıdır. Bu oran ilgili piyasanın likiditesine ilişkin bir gösterge olarak kullanılabilir. Bu oranın yüksek olması likit bir piyasaya işaret ederken, aynı zamanda borsadaki yatırımcıların portföylerini daha kısa vadeli olarak değerlendirdiklerini göstermektedir (TSPB, 2016: 22). Yatırımcılar tarafından likit piyasası olan hisse senetlerine talep fazla olacaktır. Likit piyasada hisse senetlerinin sürekli alıcısı ve satıcısı bulunmakta ve hisse senetlerinin alış ve satış fiyatları arasındaki fark en düşük seviyelerde gerçekleşmektedir. Piyasada aktif yatırımcı sayısı ne kadar fazlaysa, borsada fiyat oluşumu da sağııkı bir şekilde gerçekleşir. Yatırımcılar için likiditenin birçok önemi bulunmaktadır. Likit bir piyasa, yatııımcılara fiyatlar düşük olduğunda diğer varlıklara yeniden yatırım fırsatını erişebilir kılar. Bununla beraber likit piyasa, yatırımcıların piyasadaki hareketliliğe hızlı bir şekilde karşılık vermelerini sağlayarak riski azaltmalarına imkân tanımaktadır.

Bu çalışmanın temel amacı ekonomik, politik, finansal ve jeopolitik riskin, hisse senedi fiyatları üzerindeki etkisini ortaya koymaktır. Bu amaçla likit bir piyasa olan BiST ile ekonomik risk, politik risk, finansal 
risk ve jeopolitik risk arasındaki ilişki aylık veriler kullanılarak 1999:01-2014:12 dönemi için Toda-Yamamoto nedensellik testi ve Hacker-Hatemi-J bootstrap nedensellik testi ile incelenmiş ve sonuçlar karşılaştırılmıştır.

\section{Literatür}

Literatürde hisse senedi fiyatları üzerinde ülke riskinin etkisini araştıran çalışmalar bulunmaktadır. Yapılan çalışmalar incelendiğinde daha çok ekonomik, politik ve finansal risk primlerinin hesaplanmasında kullanılan makroekonomik göstergelere odaklanıldığı göze çarpmaktadır. Konu ile ilgili literatürdeki çalışmalar aşağıda özetlenmiştir.

Erb vd. (1996), 1984-1995 yıllarını kapsayan çalışmalarında 117 ülke için ICRG tarafından hesaplanan politik, finansal, ekonomik risk ve ülke riski primi ile hisse senedi getirileri arasındaki ilişkiyi araştırmışlardır. Araştırmanın bulguları, araştırmaya dahil edilen bütün ülkelerde ülke riski primi ile hisse senedi getirileri arasındaki negatif yönlü bir ilişkinin varlığını işaret etmektedir.

Hassan vd. (2003), 10 Orta Doğu ve Afrika ülke borsalarına yönelik yaptıkları çalışmalarında; ekonomik risk, politik risk ve finansal risk primlerinin hisse senedi piyasası getiri volatilitesi ve tahmin edilebilirliği üzerindeki etkisini 1984-1999 dönemi için araştırmışlardır. GARCH yöntemi sonuçlarına göre, ülkenin politik, finansal ve ekonomik risk primlerinin hisse senedi volatilitesini ve tahmin edilebilirliğini önemli ölçüde etkilediği tespit edilmiştir.

Mateus (2004), 1997-2002 yıllarını kapsayan çalışmasında küresel risk faktörlerinin önemini ve 13 Avrupa Birliği ülkesinin borsa performansının tahmin edilebilirliğini araştırmıştır. Araştırmanın bulgularına göre, ülke getirilerinin tahmin edilebilirliği yüksek ve değişkendir; küresel araç değişkenler özellikle Bulgaristan, Kıbrıs, Estonya, Litvanya, Romanya ve Macaristan için daha yüksek bir öngörü gücüne sahipken, yerel araç değişkenler Çek Cumhuriyeti, Letonya, Polonya ve Slovenya için daha önemlidir. Yazara göre, ülkeye özgü politik, ekonomik ve finansal risk primi faktörleri hisse senedi getirileri üzerinde önemli düzeyde ve olumsuz yönde bir etkiye sahiptir.

Clark ve Kassimatis (2004), en büyük borsaya sahip altı Latin Amerika ülkesi (Arjantin, Brezilya, Kolombiya, Meksika, Şili ve Venezuela) için finansal risk primi ile hisse senedi piyasası performansı arasındaki ilişkiyi 1985-1997 dönemi kapsamında araştırmışlardır. Yazarlar, Arjantin hariç beş ülke için finansal risk priminin borsa endekslerindeki yıllık değişimlerin yaklaşık \%12'sini açıklayan önemli bir değişken olduğu sonucunu tespit etmişlerdir. Bununla birlikte sonuçlar, ülkeye özgü hiçbir sabit etkinin olmadığını göstermekte ve beş ülkenin hepsinde de finansal risk primindeki değişikliklere duyarlılık benzerlik göstermektedir.

Yapraklı ve Güngör (2007), 1986:01-2006:12 dönemini kapsayan çalışmalarında ekonomik, politik ve finansal ülke risklerinin hisse senetleri fiyatlarına etkisini araştırmışlardır. Yazarlar çalışmalarında BiST 100 Endeksi, ekonomik, finansal ve politik risk primi değişkenlerini kullanmışlardır. Johansen-Juselius eşbütünleşme testi sonuçlarına göre, ekonomik, finansal ve politik risk primleri ile BiST 100 endeksi arasında uzun dönemli bir ilişki bulunmuştur. Granger nedensellik testleri ise ekonomik risk ve politik riskten BIST 100 endeksine doğru bir nedenselliği işaret ederken; finansal risk ile BiST 100 endeksi arasında herhangi bir nedensellik gözlenmemiştir. Bununla birlikte regresyon analizi sonuçlarına göre, ekonomik, finansal ve politik risklerin hisse senedi fiyatları arasında negatif yönlü bir ilişki bulunmuştur.

Kaya vd. (2014), Türkiye'ye ait politik risk primi ile BiST 100 Endeksi arasındaki ilişkiyi 1998:01-2012:12 dönemi için araştırmışlardır. Çalışmada Johansen-Juselius eşbütünleşme testi, Granger nedensellik testi ve regresyon analizi sonuçlarına göre; politik risk ile hisse senedi fiyatları arasında uzun dönemli bir ilişkinin varlığı, politik riskten hisse senedi fiyatlarına doğru bir nedensellik ve politik riskin hisse senedi fiyatlarını negatif yönde etkilediği tespit edilmiştir.

Kara ve Karabıyık (2015), 1999:01-2013:12 dönemini içeren çalışmalarında ICRG tarafından hesaplanan ekonomik risk primi, finansal risk primi, politik risk primi ve ülke riski bileşenleri ile BiST 100 Endeksi arasındaki ilişkiyi Johansen Eşbütünleşme testi ve Vektör Hata Düzeltme Modeline dayalı nedensellik testi ile analiz etmişlerdir. Yapılan analizler sonucunda yazarlar, ilgili risk primlerinden BiST 100 endeksine 
doğru bir nedensellik ilişkisinin varlığını ortaya koymuşlardır. Regresyon analizi sonuçlarına göre, ülke riskinin ve ülke riski bileşenlerinin hisse senedi fiyatlarını olumsuz yönde etkilediği saptanmıştır.

Mensi vd. (2015), 1995-2013 yıllarını kapsayan çalışmalarında BRICS (Brezilya, Rusya, Hindistan, Çin ve Güney Afrika) ülkelerinin borsaları ile önemli küresel ekonomik ve finansal faktörlerin varlığı altında üç ülke riski primleri (finansal, ekonomik ve politik) arasındaki asimetrik ilişkiyi araştırmışlardır. Dinamik panel eşik modeli sonuçlarına göre, çoğu durumda asimetrik kanıtlar tespit edilmiştir. Ancak BRICS ülkelerinin borsa getirisi üzerindeki bu risk primlerinin etkilerinin önemi ve işaretleri alt ve üst rejimlerde farklılık göstermektedir.

Ayaydın vd. (2016), Türkiye için; ekonomik risk, finansal risk, politik risk ve bu üç riskin bileşiminden oluşan ülke risk priminin hisse senedi fiyatları üzerindeki etkisini 2002-2015 yılları için aylık veriler kullanarak araştırmışlardır. Araştırmadan elde edilen bulgulara göre, ekonomik, finansal, politik ve ülke riski primleri ile hisse senedi getirisi arasında negatif yönlü bir ilişki tespit edilmiştir. Ayrıca nedensellik analizi sonuçları, hisse senedi getirisi ile ekonomik risk arasında çift yönlü nedenselliği; hisse senedi getirisi ve politik risk, finansal risk ve ülke riski arasında tek yönlü nedenselliği yani risk primlerinden hisse senedi getirisine doğru nedenselliği işaret etmektedir.

Tükenmez ve Kutay (2016), ICRG tarafından Türkiye ve Arjantin'e yönelik hesaplanan ülke risk primlerinin borsa endeksleri üzerindeki etkisini 1996:10-2013:12 dönemi kapsamında analiz etmişlerdir. Çalışmanın eşbütünleşme testi sonuçları, Türkiye için finansal ve politik risk primlerinin borsa endeksi ile, Arjantin için ise sadece finansal risk primi ile borsa endeksi arasında uzun dönemli bir ilişki olduğunu işaret etmektedir. Granger nedensellik testi ise her iki ülke için sadece finansal risk primi ve borsa endeksi arasında çift yönlü nedensellik ilişkisini ortaya koymuştur. Regresyon analizi sonucunda Türkiye'de ekonomik, finansal ve politik risklerin, Arjantin'de ise sadece finansal riskin hisse senedi fiyatlarını olumsuz yönde etkilediği saptanmıştır.

Karaca (2018), Türkiye'de ekonomik aktive ile hisse senedi fiyatları arasındaki nedensellik ilişkisini 2000-2016 dönemi kapsamında Toda-Yamamoto nedensellik testi ile araştırmıştır. Nedensellik testi sonuçları, Türkiye'de hisse senedi fiyatlarından ekonomik aktiviteye doğru tek yönlü nedenselliği işaret etmektedir.

\section{Ampirik Uygulama}

\subsection{Veri Seti ve Yöntem}

Bu çalışma, BiST100 Endeksi ile ekonomik, politik, finansal ve jeopolitik risk arasındaki ilişkiyi 1999:012014:12 dönemi için Toda-Yamamoto nedensellik testi ve Hacker-Hatemi J bootstrap nedensellik testi ile incelemeyi amaçlamaktadır. Ekonometrik analizler için E-Views 9 ve Gauss 10 programları kullanılmıştır. Çalışmada BIST 100 Endeksi serisi Türkiye Cumhuriyet Merkez Bankası'nın (TCMB) Elektronik Veri Dağıtım Sistemi'nin (EVDS) internet sitesinden elde edilmiştir. Ülke riskinin bileşenleri olan ekonomik risk, politik risk ve finansal risk primleri ise uygulamalı çalışmalarda sıklıkla tercih edilen ve güvenirliği yüksek olan ICRG'den sağlanmıştır. Jeopolitik risk endeksi verileri ise Economic Policy Uncertainty Index veri tabanından elde edilmiştir. Analizlerde kullanılacak değişkenlere ait kısaltmalar, tanımlamalar, veri dönemleri ve veri kaynakları Tablo 2'de gösterilmiştir.

Tablo 1. Analizlerde Kullanılacak Değişkenler ve Veri Kaynakları

\begin{tabular}{|l|l|l|c|}
\hline \multicolumn{1}{|c|}{ Değişken } & \multicolumn{1}{|c|}{ Tanım } & \multicolumn{1}{c|}{ Veri Kaynağı } & Dönem \\
\hline LnBiST100 & BisT100 Endeksi & TCMB, Elektronik Veri Dağıtım Sistemi & $1999: 01-2014: 12$ \\
\hline LnEcoR & Türkiye'nin Ekonomik Risk Primi & PRS Group ICRG Veriseti & $1999: 01-2014: 12$ \\
\hline LnPoIR & Türkiye'nin Politik Risk Primi & PRS Group ICRG Veriseti & $1999: 01-2014: 12$ \\
\hline LnFinR & Türkiye'nin Finansal Risk Primi & PRS Group ICRG Veriseti & $1999: 01-2014: 12$ \\
\hline LnGepR & Türkiye'nin Jeopolitik Risk Primi & EPU- Economic Policy Uncertainty Index & $1999: 01-2014: 12$ \\
\hline
\end{tabular}




\subsection{Birim Kök Testi}

Bir zaman serisinin istatistiksel analizine geçmeden önce, o seriyi meydana getiren sürecin zaman içerisinde sabit olup olmadığının yani serilerin durağanlık düzeylerinin incelenmesi gerekmektedir (Tatoğlu, 2013: 199). Literatürde en çok tercih edilen Dickey-Fuller (ADF; 1979, 1981), Phillips-Perron (PP; 1988), Kwiatkowski-Phillips-Schmidt-Shin (KPSS; 1992) gibi testler geleneksel birim kök testleridir. Bu birim kök testleri, ekonomik veya siyasi gelişmeler neticesinde seride oluşabilecek yapısal kırılmaları göz ardı ettiği için güçleri nispeten daha düşük olmaktadır. Yapısal kırılmaların yapılacak birim kök sınamasında göz ardı edilmesi; yapılan analiz sonuçlarını yanıltıcı hale getirebilecektir.

Çalışmada Dickey-Fuller-ADF ve Phillips-Perron-PP standart birim kök testleri uygulanarak serilerin durağanlıkları incelenmiş ve sonuçları raporlanmıştır. Diğer taraftan yapısal kırılmalar dikkate alınarak serilerin durağanlıkları iki kırımalı Narayan ve Popp (NP, 2010) birim kök testi ile sınanmıştır.

\subsection{1. İki Yapısal Kırılmalı Birim Kök Testi: Narayan ve Popp (2010)}

Narayan-Popp (NP-2010) birim kök testi, iki kırılmaya izin veren Dickey-Fuller tipi birim kök testidir. Narayan-Popp birim kök testinde Schmidt ve Philips (1992) takip edilerek veri üretme yöntemi ile aşağıdaki eşitliklere ulaşılmışır (Narayan ve Popp, 2010: 1425-1426).

$$
\begin{aligned}
& y_{t}=d_{t}+u_{t} \\
& u_{t}=\rho u_{t-1}+\varepsilon_{t} \\
& \varepsilon_{t}=\psi^{*}(L) e_{t}=A^{*}(L)^{-1} B(L) e_{t}
\end{aligned}
$$

Yukarıdaki eşitliklerdeki ifadelerden; $y_{t}$ zaman serisini, $d_{t}$ deterministik bileşeni ve $u_{t}$ ise stokastik bileşeni temsil etmektedir.

Narayan-Popp birim kök testi, seviyede iki kırılmaya izin veren (M1) ve trendle birlikte seviyede iki kırılmaya izin veren (M2) iki yapısal kırılma altında durağanlık sınamasına imkân tanımaktadır. Tahmin edilen birim kök modelleri eşitlik (4) ve (5)'teki gibi formüle edilir (Narayan ve Popp, 2010: 1426).

$$
\begin{aligned}
& \mathrm{d}_{\mathrm{t}}^{\mathrm{M} 1}=\alpha+\beta \mathrm{t}+\psi^{*}(\mathrm{~L})\left(\theta_{1} \mathrm{DU}_{1, \mathrm{t}}^{\prime}+\theta_{2} \mathrm{DU}_{2, \mathrm{t}}^{\prime}\right), \\
& \mathrm{d}_{\mathrm{t}}^{\mathrm{M} 2}=\alpha+\beta \mathrm{t}+\psi^{*}(\mathrm{~L})\left(\theta_{1} \mathrm{DU}_{1, \mathrm{t}}^{\prime}+\theta_{2} \mathrm{DU}_{2, \mathrm{t}}^{\prime}+\gamma_{1} \mathrm{DT}_{1, \mathrm{t}}^{\prime}+\gamma_{2} \mathrm{DT}_{2, \mathrm{t}}^{\prime}\right), \\
& D U_{i, \mathrm{t}}^{\prime}=1\left(t>T_{B, i}^{\prime}\right), D T_{i, t}^{\prime}=1\left(t>T_{B, i}^{\prime}\right)\left(t-T_{B, i}^{\prime}\right), \mathrm{i}=1,2 .
\end{aligned}
$$

Burada, $T_{B, i}^{\prime}, i=1,2$, olmak üzere iki kırılma tarihini göstermektedir. $\theta_{i}$ ve $\gamma_{i}$ parametreleri sırasıyla düzeyde kırılmayı ve trendde kırımayı ifade etmektedir. (4) ve (5) nolu eşitliklere $\Psi^{*}(L)$ terimlerinin dahil edilmesi zamanla kırılmaların daha yavaş gerçekleşmesini sağlar.

Seviyede kırılmaya izini veren M1 ve trendle birlikte seviyede kırılmaya izin veren M2 için birim kök hipotezinin sınamasını sağlayacak olan yapısal modeller (1) ve (5) nolu eşitliklerin birleştirilmesiyle oluşturulmuştur. M1 ve M2 için eşitlikler aşağıdaki gibidir (Narayan ve Popp, 2010: 1427):

$$
\begin{aligned}
& y_{t}^{M 1}=\rho y_{t-1}+\alpha_{1}+\beta^{*} t+\theta_{1} D\left(T_{B}^{\prime}\right)_{1, \mathrm{t}}+\theta_{2} D\left(T_{B}^{\prime}\right)_{2, \mathrm{t}}+\delta_{1} D U_{1, \mathrm{t}-1}^{\prime}+\delta_{2} D U_{2, \mathrm{t}-1}^{\prime}+\sum_{j=1}^{k} \beta_{j} \Delta y_{t-j}+e_{t} \\
& y_{t}^{M 2}=\rho y_{t-1}+\alpha_{1}+\beta^{*} t+k_{1} D\left(T_{B}^{\prime}\right)_{1, \mathrm{t}}+k_{2} D\left(T_{B}^{\prime}\right)_{2, \mathrm{t}}+\delta_{1}^{*} D U_{1, \mathrm{t}-1}^{\prime}+\delta_{2}^{*} D U_{2, \mathrm{t}-1}^{\prime}+\gamma_{1}^{*} D T_{1, t-1}^{\prime}+ \\
& \gamma_{2}^{*} D T_{2, t-1}^{\prime}+\sum_{j=1}^{k} \beta_{j} \Delta y_{t-j}+e_{t}
\end{aligned}
$$


Birim kökün varlığını test etmek için sıfır hipotezi $\left(H_{0}\right) \rho=1$, alternatif hipotez $\left(H_{1}\right) \rho<1$ ile test edilir. $\hat{\rho}^{\prime}$ nin eşitlik (6) ve (7)'de verilen $t$ istatistikleri kullanılır. Kritik değerler Monte Carlo simülasyonu ile tespit edilir ve Narayan Popp (2010) Tablo 3'te verilmektedir. Hesaplanan test istatistiği kritik değerlerden büyükse sıfır hipotezi reddedilir.

\subsection{Toda-Yamamoto (1995) Nedensellik Testi}

Toda-Yamamoto (1995) genişletilmiş Vektör Otoregresif Model (VAR) sistemine dayalı nedensellik metodudur. Bu nedensellik testi, zaman serileri ile ilgili bazı kısıtları minimize etmektedir. Toda-Yamamoto nedensellik analizinde serilerin durağan olup olmaması, aynı düzeyde bütünleşik ve/veya eş bütünleşik olup olmaması analizi etkilememektedir.

Toda-Yamamoto nedensellik analizinde değişkenlerin seviye değerleri ile bir VAR modeli tahmini gerçekleştirilmekte ve elde edilen katsayılara kısıtlar koyularak bilinen Wald istatistiği ile doğrusal ve doğrusal olmayan kısıtlar test edilerek değişkenler arasındaki nedensellik ilişkileri tespit edilebilmektedir (Emeç ve Yarbaşı, 2018: 205). Dolayısıyla herhangi bir ön test veya eşbütünleşme testine ihtiyaç olmaksızın yürütülebilen bu yaklaşım, kurulan VAR modelinin gecikme uzunluğu $(k)$ ve değişkenlerin maksimum bütünleşme derecesi $\left(d_{\max }\right)$ doğru tespit edildikten sonra $\left(k+d_{\max }\right)$ boyutunda bir VAR modeli tahmin edilir. Toda-Yamamoto yaklaşımında $\left(k+d_{\max }\right)$ gecikme uzunluğunda VAR modeli aşağıdaki gibi tahmin edilmektedir (Göktaş, Pekmezci ve Bozkur, 2018: 60-62):

$$
\begin{aligned}
& Y_{t}=\psi_{0}+\sum_{i=1}^{k} \psi_{i} Y_{t-i}+\sum_{i=k+1}^{k+d_{\max }} \psi_{i} Y_{t-i}+\sum_{i=k+1}^{k} \theta_{i} X_{t-i}+\sum_{i=k+1}^{k+d_{\max }} \theta_{i} X_{t-i}+\varepsilon_{1 t} \\
& X_{t}=\mu_{0}+\sum_{i=1}^{k} \mu_{i} X_{t-i}+\sum_{i=k+1}^{k+d_{\max }} \mu_{i} X_{t-i}+\sum_{i=1}^{k} \lambda_{i} Y_{t-i}+\sum_{i=k+1}^{k+d_{\max }} \lambda_{i} Y_{t-i}+\varepsilon_{2 t}
\end{aligned}
$$

Burada $k$ uygun gecikme uzunluğunu, $k+d_{\max }$ en yüksek bütünleşme derecesine sahip değişkenin derecesini göstermektedir. Ayrıca $\varepsilon_{1 t}$ ve $\varepsilon_{2 t}$ ilişkisiz hataları temsil etmektedir. Hata terimlerinin sıfır ortalama ve sabit bir kovaryans matrisine sahip olduğu varsayılmaktadır. Nedensellik sınaması için kurulan sıfır hipotezleri ise;

$$
\begin{aligned}
& H_{0}: \theta_{i}=0, \quad i=1,2, \ldots, k \\
& H_{0}: \lambda_{i}=0, \quad i=1,2, \ldots, k \\
& H_{1}: \text { En az bir tanesi sıfırdan farklı. }
\end{aligned}
$$

Granger nedenselliğin olmadığını ifade eden sıfır hipotezi, en az bir tanesinin sıfırdan farklı olduğunu ifade eden alternatif hipoteze karşı düzeltilmiş (Modifiye edilmiş) WALD (MWALD) test istatistiği kullanılarak sınanmaktadır. Hesaplanan MWALD testi k serbestlik dereceli $X^{2}$ tablo değerinden büyük olması durumunda hipotezler reddedilir.

\subsection{Hacker ve Hatemi-J (2012) Nedensellik Testi}

Hacker ve Hatemi-J (2006) bootstrap nedensellik testi, Toda-Yamamoto nedensellik testinin geliştirilmiş bir versiyonu olup VAR modeline dayanmaktadır. Bu testte hataların olası normal dağılma riskine karşın kullanılacak kritik değerler veri setinin durumuna uygun olarak bootstrap Monte Carlo simülasyonu ile elde edilmektedir. Hacker ve Hatemi-J (2006) bootstrap nedensellik testinde tahmin edilen VAR modeli ile gecikme uzunluğu dışsal olarak (harici olarak girilmekte) belirlenmektedir. Yazarlar bu durumu bir zayıflık olarak görmüşler ve daha sonra Hacker ve Hatemi-J (2012) testini geliştirerek gecikme uzunluğunun içsel olarak belirlenmesi mümkün hale gelmiştir (Göçer ve Bulut, 2015: 733).

Hacker ve Hatemi-J (2012) Granger nedenselliğini test etmek için aşağıdaki Vektör Otoregresif (VAR) modelini kullanmaktadır (Hacker ve Hatemi-J, 2012: 146): 


$$
y_{t}=B_{0}+B_{1} y_{t-1}+\ldots+B_{k} y_{t-k}+u_{t}
$$

Burada, $y_{t}, B_{0}$ ve $u_{t}$ sırasıyla $n \times 1$ boyutlu vektörü, $B_{i}, i \geq 1 \mathrm{n} \times \mathrm{n}$ boyutlu katsayılar matrisini ve $u_{t}$ beklenen değeri sıfır olan hata terimini göstermektedir. $\Omega$ ile ifade edilen bu vektörün regüler matrisi ile eş dağılımlı ve bağımsız olduğu varsayılmaktadır. Aynı zamanda, $\Omega$ bazı $\lambda>0$ değerleri için $E\left|u_{i t}\right|^{2+\lambda}<\infty$ koşulu sağlanmakta olup, burada $u_{i t}, u_{t}^{\prime}$ nin i'inci unsurudur (uygun test koşulları için bu varsayım gereklidir). Yalnızca aşağıdaki önermenin doğru olması halinde; sıfır hipotezi $\left(H_{0}\right)$ yt'nin $r^{\prime}$ inci unsurundan $j^{\prime}$ inci unsuruna nedensellik olup olmadığı test edilmektedir.

$H_{0}: B_{i^{\prime}} \operatorname{nin} J$ satırı ve $r$ sütunundaki unsuru sıfırdır. $\mathrm{i}=1, \ldots, \mathrm{k}$.

Hacker ve Hatemi-J (2012) testinde uygun gecikme uzunluğu içsel olarak belirlenmektedir ve kullanılan Schwarz Bayesian Kriteri (SBC) şöyle tanımlanmıştır (Hacker ve Hatemi-J, 2012: 147):

$$
S B C=\operatorname{Ln}\left(\operatorname{det} \bar{\Omega}_{j}\right)+k\left(\frac{n^{2} \operatorname{Ln} T}{T}\right)
$$

Burada $\bar{\Omega}_{j}$; tahmin edilen varyans-kovaryans matrisinin determinantı, $k$; gecikme uzunluğu, $T$ ise gözlem sayısını ve In ise doğal logaritmayı göstermektedir. Bu testin sıfır hipotezi, "Birinci değişkenden, ikinci değişkene doğru bir nedensellik ilişkisinin yoktur" şeklindedir.

\section{Bulgular}

\subsection{Birim Kök Testi Sonuçları}

Çalışmada değişkenlere ilişkin ilişkin ADF (Augmented Dickey-Fuller) ve PP (Philips-Perron) birim kök test sonuçları Tablo 3'te verilmiştir.

\begin{tabular}{|c|c|c|c|c|c|}
\hline \multirow{2}{*}{\multicolumn{2}{|c|}{ Değişken }} & \multicolumn{2}{|c|}{ ADF Test İstatistiği } & \multicolumn{2}{|c|}{ PP Test İstatistiği } \\
\hline & & Sabitli & Sabitli ve Trendli & Sabitli & Sabitli ve Trendli \\
\hline \multicolumn{2}{|c|}{ LnBIST100 } & $-0,343$ & $-2,990$ & $-0,474$ & $-2,884$ \\
\hline \multicolumn{2}{|c|}{ LnEcoR } & $-2,859^{*}$ & $-4,355^{* *}$ & $-2,063$ & $-4,345^{* * *}$ \\
\hline \multicolumn{2}{|c|}{ LnPolR } & $-2,057$ & $-2,416$ & $-2,007$ & $-2,360$ \\
\hline \multicolumn{2}{|c|}{ LnFinR } & $-2,093$ & $-3,066$ & $-2,076$ & $-4,002^{* * *}$ \\
\hline \multicolumn{2}{|c|}{ LnGepR } & $-4,006^{* * *}$ & $-4,551^{* * *}$ & $-6,625^{* * *}$ & $-6,777^{* * *}$ \\
\hline \multicolumn{2}{|c|}{$\Delta \mathrm{LnBIST} 100$} & $-11,746^{* * *}$ & $-11,729^{* * *}$ & $-11,743^{* * *}$ & $-11,725^{* * *}$ \\
\hline \multicolumn{2}{|c|}{$\Delta \mathrm{LnEcoR}$} & $-15,532^{* * *}$ & $-15,491^{* * *}$ & $-15,220^{* * *}$ & $-15,175^{* * *}$ \\
\hline \multicolumn{2}{|c|}{$\Delta$ LnPolR } & $-15,822^{* * *}$ & $-15,992^{* * *}$ & $-15,822^{* * *}$ & $-16,129^{* * *}$ \\
\hline \multicolumn{2}{|c|}{$\Delta$ LnFinR } & $-16,650^{* * *}$ & $-16,617^{* * *}$ & $-16,863^{* * *}$ & $-16,832^{* * *}$ \\
\hline \multicolumn{2}{|c|}{$\Delta$ LnGepR } & $-10,110^{* * *}$ & $-10,130^{* * *}$ & $-35,268^{* * *}$ & $-38,886^{* * *}$ \\
\hline \multirow{3}{*}{ Kritik Değerler } & $\% 1$ & $-3,464$ & $-4,006$ & $-3,464$ & $-4,006$ \\
\hline & $\% 5$ & $-2,876$ & $-3,434$ & $-2,876$ & $-3,434$ \\
\hline & $\% 10$ & $-2,574$ & $-3,141$ & -2574 & $-3,141$ \\
\hline
\end{tabular}

Tablo 3. ADF ve PP Birim Kök Test Sonuçları

Not: ${ }^{* * *},{ }^{* *}$ ve ${ }^{*}$ işaretleri \%1, \%5 ve \%10 düzeylerinde seri birim kök içermektedir şeklinde oluşturulan sıfır hipotezinin reddedildiğini göstermektedir. $\Delta$, birinci fark işlemcisidir. 
Tablo 3'te rapor edilen test istatistikleri sabitli ve sabitli ve trendli değerleri içermektedir. Uygulanan $A D F$ ve PP testleri LnBIST100, LnPolR ve LnFinR değişkenlerinin düzeyde durağan olmadığını ancak birinci farkında durağan olduğunu; LnEcoR ve LnGepR değişkenlerinin düzeyde durağan olduklarını göstermektedir. Çalışmada serilerin genel eğilimi göstermek adına Şekil 1'de değişkenlerin grafikleri verilmiştir.

Şekil 1. Çalışmada Kullanılan Serilerin Grafiksel Gösterimi

$\operatorname{lnBIST} 100$

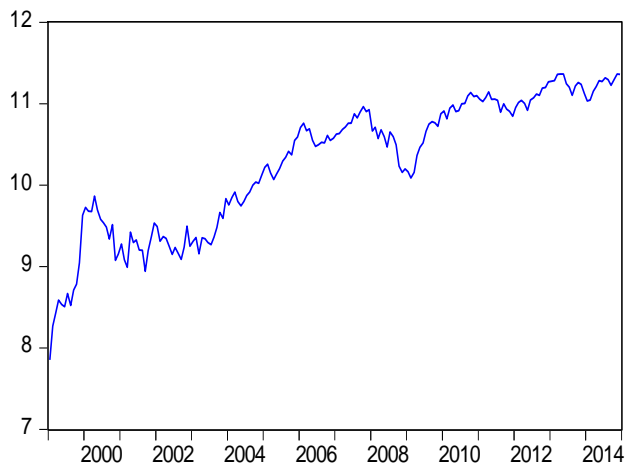

InFRR

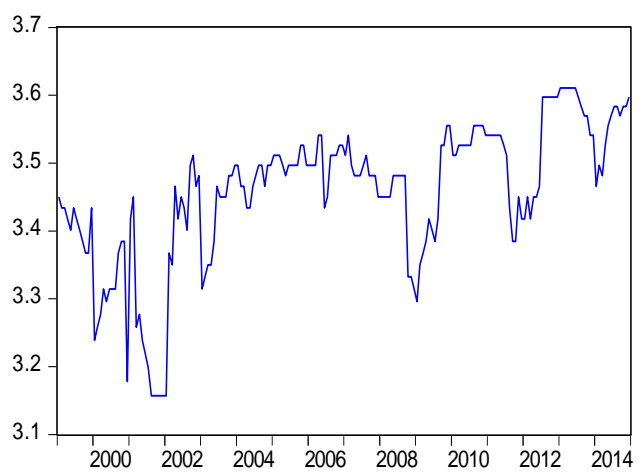

InPRR

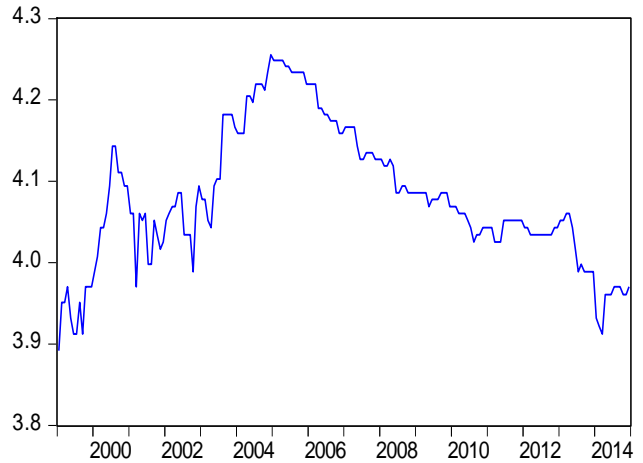

$\operatorname{lnECR}$

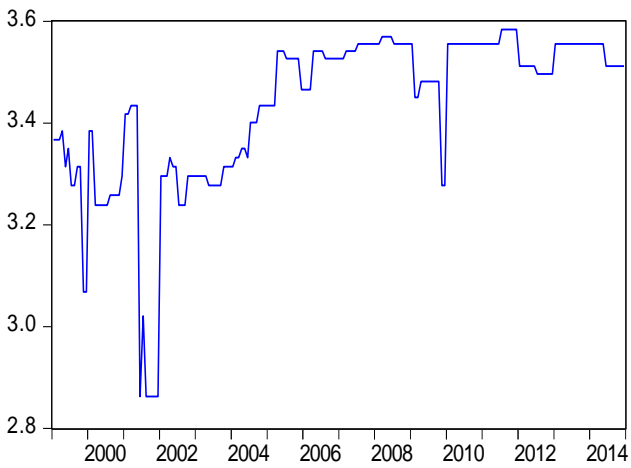

$\operatorname{lnGPR}$

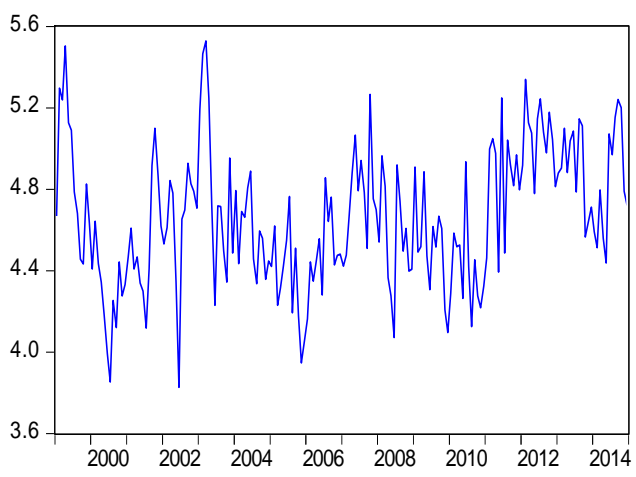

Bu çalışmada yapısal kırılmayı dikkate alan Narayan-Popp (NP-2010) birim kök testi ile serilerin durağanlıkları araştııılmış ve birim kök test sonuçları Tablo 4'te verilmiştir. Hesaplanan test istatistiği kritik değerlerden büyükse sıfır hipotezi reddedilir. Kritik değerler Narayan ve Popp (2010) Tablo 3'te verilmektedir. 
Farklı Risk Türleri ve Borsa Endeksi Arasındaki İlişki: Türkiye İçin Nedensellik Testleri

Tablo 2. Narayan ve Popp (2010) Birim Kök Test Sonuçları

\begin{tabular}{|c|c|c|c|c|c|}
\hline \multirow{2}{*}{\multicolumn{2}{|c|}{ Değişken }} & \multicolumn{2}{|c|}{ Test İstatistikleri } & \multicolumn{2}{|c|}{ Kırılma Tarihleri } \\
\hline & & M1 & M2 & M1 & M2 \\
\hline \multicolumn{2}{|l|}{ LnBIST100 } & $-3,034$ & $-4,298$ & 2002-11;2008-09 & 2002-10;2008-09 \\
\hline \multicolumn{2}{|l|}{ LnEcoR } & $-4,727^{b}$ & $-5,174^{b}$ & 2009-10;2009-12 & 2009-10;2010-01 \\
\hline \multicolumn{2}{|l|}{ LnPolR } & $-4,649^{b}$ & $-3,925$ & 2002-10;2003-07 & 2002-10;2003-07 \\
\hline \multicolumn{2}{|l|}{ LnFinR } & $-04,139^{b}$ & $-4,778^{b}$ & 2002-12;2008-09 & 2002-12;2008-09 \\
\hline \multicolumn{2}{|l|}{ LnGepR } & $-8,109^{a}$ & $-8,087^{a}$ & 2007-09;2011-05 & 2007-09;2011-05 \\
\hline \multicolumn{2}{|l|}{$\Delta$ LnBIST100 } & $-14,810^{\mathrm{a}}$ & $-14,940^{\mathrm{a}}$ & 2002-09;2007-11 & 2002-09;2007-11 \\
\hline \multicolumn{2}{|l|}{$\Delta$ LnEcoR } & $-7,195^{a}$ & $-7,145^{a}$ & 2009-09;2009-11 & 2009-09;2009-11 \\
\hline \multicolumn{2}{|l|}{$\Delta$ LnPolR } & $-15,820^{\mathrm{a}}$ & $-15,690^{\mathrm{a}}$ & 2002-09;2003-06 & 2002-09;2003-03 \\
\hline \multicolumn{2}{|l|}{$\Delta$ LnFinR } & $-17,170^{\mathrm{a}}$ & $-12,650^{\mathrm{a}}$ & 2002-11;2008-08 & 2002-11;2008-08 \\
\hline \multicolumn{2}{|l|}{$\Delta \mathrm{LnGepR}$} & $-11,020^{\mathrm{a}}$ & $-10,540^{\mathrm{a}}$ & 2002-04;2003-04 & 2002-04;2003-04 \\
\hline \multirow{3}{*}{ Kritik Değerler } & $\% 1$ & $-4,731$ & $-5,318$ & & \\
\hline & $\% 5$ & $-4,136$ & $-4,741$ & & \\
\hline & $\% 10$ & $-3,825$ & $-4,430$ & & \\
\hline
\end{tabular}

Not: Kritik değerler Narayan ve Popp (2010)'un çalışmalarındaki Tablo 3'ten elde edilmiştir. a, b, c sırasıyla \%1, \%5 ve \%10 düzeylerinde anlamlılığı ifade etmektedir.

Narayan ve Popp (2010) yapısal kırılmalı birim kök testinden elde edilen kırılma tarihlerinden 2002 yılı, 2001 krizinden sonraki dönemde Türkiye ekonomisinin toparlanma sürecine ve güçlü ekonomiye geçiş programının etkilerine ve Kasım 2002 tarihinde yapılan genel seçimlerde Adalet ve Kalkınma Partisi'nin tek başına iktidara geldiği tarihe işaret etmektedir. 2007 yılı sonunda patlak veren ve 2009 yılı sonarına kadar süren ve yine tüm dünya ekonomilerini etkileyen 2008 küresel finans krizi 2008 yılında bulunan kırılmaları açıklamaktadır. Yapısal kırılmalı birim kök testi sonuçlarına dayanarak borsa endeksi üzerinde politik ve ekonomik değişmelerin etkisinin, yansımasının olduğunu söylemek mümkündür.

\subsection{Toda-Yamamoto (1995) Nedensellik Testi Sonuçları}

Çalışmanın yöntem kısmında da belirtildiği üzere, Toda-Yamamoto (1995) nedensellik testi, içsel değişkenlerin $k+d$ gecikmeli VAR modelini gerektirmektedir. Toda-Yamamoto (1995) nedensellik testi için kurulacak VAR modelinin uygun gecikme uzunluğunun $(k)$ tespit edilmesi gerekir. Bunun için beş bilgi kriterine başvurulmuş ve bilgi kriterleriyle ilgili sonuçlar Tablo 5'te rapor edilmiştir.

Tablo 3. VAR Modelinin Optimal Gecikme Uzunluğunun Belirlenmesi

\begin{tabular}{|c|c|c|c|c|c|}
\hline Gecikme SayISI & LR & FPE & AIC & SC & HQ \\
\hline 0 & - & $1,56 \mathrm{e}-09$ & $-6,091794$ & $-5,918367$ & $-6,021515$ \\
\hline 1 & 1122,023 & $3,86 \mathrm{e}-12$ & $-12,09126$ & $-11,48427^{*}$ & $-11,84529^{*}$ \\
\hline 2 & 49,81521 & $3,80 \mathrm{e}-12$ & $-12,10874$ & $-11,06818$ & $-11,68706$ \\
\hline 3 & 57,03391 & $3,55 \mathrm{e}-12$ & $-12,17740$ & $-10,70327$ & $-11,58003$ \\
\hline 4 & $44,74551^{*}$ & $3,55 \mathrm{e}-12^{*}$ & $-12,18142^{*}$ & $-10,27372$ & $-11,40835$ \\
\hline 5 & 34,73064 & $3,75 \mathrm{e}-12$ & $-12,13104$ & $-9,789770$ & $-11,18227$ \\
\hline 6 & 39,69650 & $3,81 \mathrm{e}-12$ & $-12,11999$ & $-9,345154$ & $-10,99552$ \\
\hline
\end{tabular}

Not: LR (Sequential Modifeild), FPE (Final Prediction Error), AIC (Akaike), SC (Schwarz), HQ (Hannan-Quin). *: ilgili kritere ait minimum değerini göstermekte ve o değere karşılık gelen gecikme de en uygun gecikme uzuluğu olarak önerilmektedir. 
Tablo 5'e göre SC ve HQ kriterleri 1 gecikmenin, LR, FPE ve AIC 4 gecikmenin uygun olduğunu göstermektedir. Tespit edilen gecikme uzunluğunda kurulan VAR modelinin sonuçlarının güvenilir olabilmesi için otokorelasyon, değişen varyans gibi kısıtları sağlamalıdır. Kurulan VAR modeli otokorelasyon problemi taşıyorsa gecikme uzunluğunun otokorelasyon problemi ortadan kaldırılacak şekilde değiştirilmesi gerekmektedir. Tablo 6'da 1 gecikmeli VAR modeli için yapılan LM (Lagrange Çarpanı) testi hata terimlerinde otokorelasyon ve değişen varyans olduğunu göstermiştir. Tablo 6'daki LM testi sonuçlarına göre VAR modeli 4 gecikme ile kurulmuştur. Bu sonuçlardan hareketle Toda-Yamamoto testi kullanılarak BiST100 Endeksi ile ekonomik, politik, finansal ve jeopolitik risk arasındaki ilişkinin yönünün belirlemeye yönelik bir analiz yapılabilir. Kısıtlanmış VAR modeli için $k=4$ ve $d_{\max }=1$ olduğundan VAR modeli $k+d_{\max }=4+1=5$ gecikme ile kurulmuştur. Daha sonra k gecikmeli değerlere Wald testi yapılmış ve ki-kare istatistiği hesaplanarak nedensellik ilişkisinin olup olmadığı tespit edilmiştir.

Tablo 6. VAR Modeli İçin Otokorelasyon LM Test Sonuçları

\begin{tabular}{|c|c|c|c|c|}
\hline \multirow{2}{*}{ Testin Gecikme Sayısı } & \multicolumn{2}{|c|}{ 1 Gecikmeli VAR Modeli } & \multicolumn{2}{c|}{ 4 Gecikmeli VAR Modeli } \\
\cline { 2 - 5 } & LM istatistiği & Olasılık Değeri & \multirow{2}{*}{ LM istatistiği } & Olasıllı Değeri \\
\hline 1 & 46,43170 & $0,0057^{*}$ & 20,28130 & 0,7319 \\
\hline 2 & 34,98875 & 0,8840 & 44,12116 & 0,1050 \\
\hline 3 & 52,26604 & $0,0011^{*}$ & 28,58452 & 0,2817 \\
\hline 4 & 29,20074 & 0,2556 & 28,93069 & 0,2668 \\
\hline 5 & 39,15221 & $0,0356^{* *}$ & 29,02795 & 0,2627 \\
\hline 6 & 32,33614 & 0,1485 & 28,03458 & 0,3063 \\
\hline
\end{tabular}

Not: ${ }^{* * *}, * * *$ sırasıyla $\% 1, \% 5$ ve $\% 10$ istatistiksel anlamlılık seviyelerinde ardışık anlamlılığı göstermektedir.

Tablo 7'de BiST100 Endeksi ile ekonomik, politik, finansal ve jeopolitik risk arasındaki TodaYamamoto nedensellik testi sonuçları yer almaktadır.

Tablo 4. Toda-Yamamoto Nedensellik Test Sonuçları

\begin{tabular}{|c|c|c|c|c|}
\hline İlişkinin Yönü & $\begin{array}{c}\text { Gecikme Uzunluğu } \\
\left(k+d_{\max }\right)\end{array}$ & $\begin{array}{c}\text { MWALD } \\
\left(x^{2} \text { istatistiği) }\right.\end{array}$ & $\begin{array}{c}P \\
\text { (Olasılık) Değeri }\end{array}$ & Sonuç \\
\hline EcoR $\neq>$ BisT & 5 & 17,9269 & $0,0013^{*}$ & $\mathrm{H}_{0} \mathrm{RED}$ \\
\hline BiST $\neq>$ EcoR & 5 & 15,8632 & $0,0032^{*}$ & $\mathrm{H}_{0} \mathrm{RED}$ \\
\hline PolR $\neq>$ BisT & 5 & 11,8548 & $0,0185^{* *}$ & $\mathrm{H}_{0} \mathrm{RED}$ \\
\hline BiST $\neq>$ PolR & 5 & 21,1189 & $0,0003^{*}$ & $\mathrm{H}_{0} \mathrm{RED}$ \\
\hline Fin $R \neq>$ BiST & 5 & 3,7456 & 0,4415 & $\mathrm{H}_{0} \mathrm{KABUL}$ \\
\hline BiST $\neq>$ FinR & 5 & 13,9592 & $0,0074^{*}$ & $\mathrm{H}_{0}$ RED \\
\hline GepR $\neq>$ BisT & 5 & 1,8648 & 0,7606 & $\mathrm{H}_{0} \mathrm{KABUL}$ \\
\hline BiST $\neq>$ GepR & 5 & 5,8236 & 0,2127 & $\mathrm{H}_{0} \mathrm{KABUL}$ \\
\hline
\end{tabular}

Not: ${ }^{*}, * * * * *$ sırasıyla \%1, \%5 ve \%10 anlamlılık düzeyinde sıfır hipotezinin reddedildiğini ve nedensellik ilişkisinin kabul edildiğini göstermektedir. Tablodaki $\neq>$ notasyonu ilgili değişken arasında gösterilen yönde nedensellik ilişkisi olmadığı hipotezini ifade etmektedir.

Tablo 7'deki Toda-Yamamoto nedensellik sonuçlarına göre; ekonomik risk priminden ve politik risk priminden BIST100 Endeksine doğru bir nedenselliğin olmadığını ifade eden sıfır hipotezi $\left(\mathrm{H}_{0}\right)$ sırasıyla \%1 ve $\% 5$ anlamlılık düzeyinde reddedilmektedir. Finansal risk priminden ve jeopolitik risk priminden BiST100 
Endeksine doğru bir nedenselliğin olmadığını ifade eden sıfır hipotezi $\left(\mathrm{H}_{0}\right)$ ise reddedilememektedir. TodaYamamoto nedensellik testi sonuçları, ekonomik risk priminden ve politik risk priminden BiST100 Endeksine doğru bir nedenselliğin olduğunu ortaya koymaktadır. Karşılıklı nedensellik ilişkisini incelemek adına BiST100 Endeksinden risk primlerine doğru olan nedensellik ilişkisi incelendiğinde, BIST100 Endeksi ile ekonomik risk primi ve politik risk primi arasında çift yönlü nedensellik ilişkisi tespit edilmiştir. BiST100 Endeksinden finansal risk primine doğru \%1 anlamlılık düzeyinde tek yönlü nedensellik ilişkisinin olduğu sonucuna ulaşılmıştır. BIST100 Endeksinden jeopolitik risk primine doğru ise herhangi bir nedensellik ilişkisine rastlanmamıştır.

\subsection{Hacker ve Hatemi-J (2012) Bootstrap Nedensellik Testi Sonuçları}

Gecikme uzunluğunun içsel olarak belirlendiği Hacker ve Hatemi-J (2012) testinde birinci değişkenden ikinci değişkene doğru bir nedensellik ilişkisini gösteren MWALD istatistik değerleri, bootstrap yöntemi ile elde edilen kritik değerlerden küçük olması durumunda nedensellik ilişkisini olmadığını ifade eden sıfır hipotezi $\left(\mathrm{H}_{0}\right)$ reddedilemeyerek nedensellik ilişkisinin olmadığına karar verilmektedir. Çalışmada Hacker ve Hatemi-J (2012) nedensellik testi yapılmış ve sonuçları Tablo 8'de rapor edilmiştir.

Tablo 5. Hacker ve Hatemi-J (2012) Bootstrap Nedensellik Testi Sonuçları ${ }^{\mathrm{a}}$

\begin{tabular}{|c|c|c|c|c|c|}
\hline \multirow{2}{*}{ Hipotezler } & \multirow{2}{*}{ MWALD Test İstatistiği } & \multicolumn{3}{|c|}{ Bootstrap Kritik Değerlerib } & \multirow{2}{*}{ Karar } \\
\hline & & $\% 1$ & $\% 5$ & $\% 10$ & \\
\hline EcoR $\neq>$ BiST & $25,546^{*}$ & 25,314 & 19,127 & 16,406 & $\mathrm{H}_{0} \mathrm{RED}$ \\
\hline BiST $\neq>$ EcoR & $12,104^{*}$ & 7,416 & 4,006 & 2,784 & $\mathrm{H}_{0}$ RED \\
\hline PolR $\neq>$ BisT & $3,868^{* *}$ & 6,656 & 3,733 & 2,700 & $\mathrm{H}_{0} \mathrm{RED}$ \\
\hline BiST $\neq>$ PolR & $4,944^{* *}$ & 10,149 & 4,601 & 2,822 & $\mathrm{H}_{0} \mathrm{RED}$ \\
\hline FinR $\neq>$ BiST & 0,057 & 6,864 & 3,993 & 2,776 & $\mathrm{H}_{0} \mathrm{KABUL}$ \\
\hline BiST $\neq>$ FinR & $7,408^{*}$ & 7,073 & 3,868 & 2,705 & $\mathrm{H}_{0}$ RED \\
\hline GepR $\neq>$ BisT & 0,544 & 6,794 & 3,997 & 2,698 & $\mathrm{H}_{0} \mathrm{KABUL}$ \\
\hline BiST $\neq>$ GepR & 0,915 & 6,622 & 4,026 & 2,830 & $\mathrm{H}_{0} \mathrm{KABUL}$ \\
\hline
\end{tabular}

Not: a: Optimum gecikme uzunluğu HJC Bilgi kriteri ile belirlenmiştir. b: Bootstrap kritik değerleri 10.000 döngüyle elde edilmiştir. $*, * *, * * *$ sırasıyla \%10, \%5 ve \%1 anlamlııı düzeyinde birinci değişkenden ikinci değişkene doğru bir nedensellik ilişkisinin varlığını göstermektedir. Tablodaki $\neq>$ notasyonu ilgili değişken arasında gösterilen yönde nedensellik ilişkisi olmadığı hipotezini ifade etmektedir.

Tablo 8'deki sonuçlar incelendiğinde; ekonomik risk primi ve politik risk primi ile BiST100 Endeksi arasında çift yönlü nedensellik ilişkisinin olduğu görülmüştür. Yine tablodaki sonuçlara göre; finansal risk pirimi ve jeopolitik risk pirimi ile BiST100 Endeksi arasında nedensellik ilişkisinin olmadığı tespit edilmiştir. Ancak BiST100 Endeksinden finansal risk primine doğru tek yönlü bir nedensellik ilişkisinin olduğu görülmektedir. Hacker ve Hatemi-J (2012) bootstrap nedensellik testi sonuçları ile Toda-Yamamoto nedensellik testi sonuçları örtüşmektedir.

\section{Sonuç}

Hisse senedi fiyatları finansal piyasaların gelişmesiyle birlikte ekonomik, sosyal ve politik gelişmelere karşı daha duyarlı hale gelmiştir. Dolayısıyla yatırımcılar gerek doğrudan gerekse dolaylı olarak bir ülke ekonomisinin ekonomik, politik ve finansal durumundan etkilenmektedir. Bu bağlamda düşünüldüğünde hisse senedi piyasaları yalnızca hisse senedi alım-satım kararlarının verildiği pazarlar değil, aynı zamanda fonların toplandığı, toplanan fonların talep edenlere optimal biçimde, en düşük maliyetle ve etkin bir şekilde aktarıldığı, risklerin dağıtıldığı ortamlardır.

Bu çalışmada, ekonomik risk pirimi, politik risk pirimi, finansal risk primi ve jeopolitik risk pirimi ile BiST100 Endeksi arasındaki ilişki 1999:01-2014:12 dönemi için Toda-Yamamoto nedensellik testi ve HackerHatemi J bootstrap nedensellik testi ile incelenmiştir. Bu kapsamda ilk olarak, maksimum durağanlık derecesini belirlemek için birim kök testlerine yer verilmiştir. Çeşitli bilgi kriterlerinden faydalanarak uygun 
gecikme uzunluğu belirlenmiştir. Tespit edilen gecikme uzunluğunda kurulan VAR modelinin sonuçlarının güvenilir olabilmesi için otokorelasyon, değişen varyans gibi kısıtları sağlaması için LM testi sonuçlarına göre VAR modeli kurulmuştur. Toda-Yamamoto nedensellik testi sonuçları incelenen risk primlerinden ekonomik risk primi ve politik risk primi ile BIST100 Endeksi arasında çift yönlü nedensellik ilişkisinin olduğunu göstermektedir. Ancak finansal risk priminden ve jeopolitik risk priminden BiST100 Endeksine doğru bir nedenselliğin olmadığı görülmektedir. Yine çalışmanın bulgularına göre BiST100 Endeksinden finansal risk primine doğru tek yönlü nedensellik ilişkisi bulunmaktadır. Hacker ve Hatemi-J (2012) bootstrap nedensellik testi sonuçları da Toda-Yamamoto nedensellik testi sonuçlarını doğrulamaktadır. Hacker ve Hatemi-J (2012) bootstrap nedensellik testin sonuçları ekonomik risk primi ve politik risk primi ile BIST100 Endeksi arasında çift yönlü nedensellik ilişkisinin varlığını işaret etmektedir. Yine bu testin sonuçlarına göre, finansal risk pirimi ve jeopolitik risk pirimi ile BIST100 Endeksi arasında nedensellik ilişkisi bulunmazken; BIST100 Endeksinden finansal risk primine doğru tek yönlü bir nedensellik ilişkisi bulunmaktadır. Sonuç itibariyle her iki nedensellik testinin sonuçları örtüşmektedir.

Literatürde konu ile ilgili yapılan çalışmalar incelendiğinde genel olarak ülke riskinin (ekonomik, politik ve finansal risk) artmasının hisse senedi fiyatlarını olumsuz yönde etkilediği sonucu ortaya konmuştur. Bu çalışmanın bulgusu, literatürde daha önce yapılan çalışmaların (Erb vd., 1996; Clark ve Kassimatis, 2004; Yapraklı ve Güngör, 2007; Kaya vd., 2014; Kara ve Karabıyık, 2015; Ayaydın vd., 2016; Tükenmez ve Kutay, 2016) sonuçlarını desteklemektedir.

Çalışmada uygulanan nedensellik testleri, makroekonomik değişkenlere dayalı ekonomik risk primi ve ülkenin siyasi yapısını gösteren politik risk primi ile hisse senedi fiyatları arasında çift yönlü nedensellik ilişkisinin olduğunu göstermektedir. Finansal risk priminden ve jeopolitik risk priminden hisse senedi fiyatlarına doğru bir nedensellik bulunmaktadır. Bu çalışmada hisse senedi fiyatlarıyla risk primleri arasındaki nedensellik ilişkisini araştırarak literatüre katkı sağlamaya çalışılmıştır. Elde edilen sonuçlar, borsanın ekonominin, sosyal ve politik yaşamın bir barometresi olarak çalıştığı görüşünü desteklemektedir.

Yatırımcılar, menkul kıymet piyasalarında risk ve getiri tercihlerine göre karar verirler. Bireysel ve kurumsal yatırımcılar özellikle de portföy yöneticileri riski yüksek olan hisse senedi yatırımlarında ülke riski düşük olan ülkeleri tercih edeceklerdir. Hisse senedi fiyatlarını etkileyen ülke risklerinin tespiti, finansal piyasaların gelişmesi için gerekli politika değişikliklerine yol gösterebileceği gibi hisse senedi yatırımını daha cazip hale getirebilecektir.

\section{Beyan ve Açıklamalar (Disclosure Statements)}

1. Bu çalışmanın yazarı, araştırma ve yayın etiği ilkelerine uyduğunu kabul etmektedir (The author of this article is admitted that he/she complied with the principles of research and publication ethics).

2. Yazar tarafından herhangi bir çıkar çatışması beyan edilmemiştir (No potential conflict of interest was reported by the author).

3. Bu çalışma, intihal tarama programı kullanılarak intihal taramasından geçirilmiştir (This article was screened for potential plagiarism using a plagiarism screening program).

\section{Kaynaklar}

Albeni, M., \& Demir, Y. (2005). Makroekonomik göstergelerin mali sektör hisse senedi fiyatlarına etkisi (iMKB uygulamalı). Muğla Üniversitesi SBE Dergisi, 14, 1-18.

Ayaydın, H., Pala, F., \& Barut, A. (2016). Ülke riskinin hisse senedi getirisine etkisi: Ampirik analiz. Global Journal of Economics and Business Studies, 5(10), 66-75.

Ceylan, A., \& Korkmaz, T. (2015). İ̧̧letmelerde finansal yönetim (14. Basım). Bursa: Ekin Basın Yayın Dağııım.

Clark, E., \& Kassimatis, K. (2004). Country financial risk and stock market performance: The case of Latin America. Journal of Economics and Business, 56, 21-41. 
Farklı Risk Türleri ve Borsa Endeksi Arasındaki İlişki: Türkiye İçin Nedensellik Testleri

Coşkun, N., Ardor, N. H., Çermikli, H., Eruygur, O., Öztürk, F., Tokatlıoğlu, İ., Aykaç, G., \& Dağlaroğlu, T. (2012). Türkiye'de bankacılık sektörü piyasa yapısı, firma davranışları ve rekabet analizi. https://www.tbb.org.tr/Content/Upload/Dokuman/796/rekabetKitap.pdf (Erişim Tarihi: 10.12.2018).

Dickey, D. A., \& Fuller, W. A. (1979). Distribution of the estimators for Autoregressive Time Series with a Unit Root. Journal of the American Statistical Association, 74, 427-431.

Dickey, D. A., \& Fuller, W. A. (1981). Distribution of the Estimators for Autoregressive Time Series with a Unit Root. Econometrica, 49, 1057-72.

Emeç, S. A., \& Yarbaşı, Y. İ. (2018). Ticari dışa açıklık ile enerji tüketimi arasındaki simetrik ve asimetrik nedensellik ilişkisi: Türkiye örneği. Erzurum Teknik Üniversitesi SBE Dergisi, 3(6), 199-212.

Erb, B. C., Harvey, R. C., \& Viskanta, E. T. (1996). Political risk, economic risk and financial risk. Financial Analysts Journal, 52(6), 29-46.

Ercan, K. M., \& Ban, Ü. (2005). Değere dayalı işletme finansı (8. Baskı). Ankara: Gazi Kitabevi.

Göçer, İ., \& Bulut, Ş. (2015). Petrol fiyatlarındaki değişimlerin Rusya ekonomisine etkileri: Çoklu yapısal kırılmalı esbütünlesme ve simetrik nedensellik analizi. Çankırı Karatekin Üniversitesi iktisadi ve Idari Bilimler Fakültesi Dergisi, 5(2), 721-748.

Göktaş, P., Pekmezci, A., \& Bozkurt, K. (2018). Ekonometrik serilerde uzun dönem eşbütünleşme ve kısa dönem nedensellik ilişkileri (Eviews ve Stata uygulamaları). Ankara: Gazi Kitabevi.

Hacker, S., \& Hatemi-J, A. (2012). A bootstrap test for causality with endogenous lag length choice: Theory and application in finance. Journal of Economic Studies, 39(2), 144-160.

Hassan, M. K., Maroney, C. N., El-Sady, H. M., \& Telfah, A. (2003). Country risk and stock market volatility, predictability, and diversification in the Middle East and Africa. Economic Systems, 27(1), 63-82.

Kara, E., \& Karabıyık, L. (2015). The effect of country risk on stock prices: An application in Borsa İstanbul. Suleyman Demirel University the Journal of Faculty of Economics and Administrative Sciences, 20(1), 225-239.

Karaca, O. (2018). Borsa ekonomini barometresi midir? Türkiye'de ekonomik aktivite ile hisse senedi fiyatları arasındaki nedensellik ilişkisi. Hacettepe Üniversitesi Iktisadi ve Idari Bilimler Fakültesi Dergisi, 36(3), 89-106.

Karan, M. B. (2004). Yatırım analizi ve portföy yönetimi. Ankara: Gazi Kitabevi.

Kaya, A., Güngör, B., \& Özçomak, S. M. (2014). Politik risk yatırımcının dikkate alması gereken bir risk midir? Borsa İstanbul örneği. Gazi Üniversitesi Iktisadi ve Idari Bilimler Fakültesi Dergisi, 16(1), 74-87.

Kwiatkowski, D., Phillips, P.C.B., Schmidt, P., \& Shin, Y. (1992). Testing the null hypothesis of stationary against the alternative of a Unit Root: How sure are we that economic time series have a Unit Root? Journal of Econometrics, 54(1-3), 159-178.

Mateus, T. (2004). The risk and predictability of equity returns of the EU accession countries. Emerging Markets Review, 5, 241-266.

Mensi, W., Hammoudeh, S., Yoon, S. M., \& Nguyen, D. K. (2015). Asymmetric linkages between BRICS stock returns and country risk ratings: Evidence from dynamic panel threshold models. Review of International Economics, 24(1), 1-19.

Narayan, K. P., \& Popp, S. (2010). A new unit root test with two structural breaks in level and slope at unknown time. Journal of Applied Statistics, 37(9), 1425-1438.

Phillips, P. C. B., \& Perron, P. (1988). Testing for a unit root in time series regression. Biometrika, 75(2), 335-346.

Tatoğlu, Y. F. (2013). Ileri panel veri analizi-stata uygulamalı (2. Baskı). İstanbul: Beta Basım Yayın Dağıtım A.Ş.

Toda, H. Y., \& Yamamoto, T. (1995). Statistical inference in Vector Autoregressions with possibly integrated processes. Journal of Econometrics, 66(1-2), 225-250.

Tükenmez, M. N., \& Kutay, N. (2016). Ülke riskinin hisse senetleri getirileri üzerine etkisi: Türkiye ve Arjantin piyasaları için bir karşılaştırma. Atatürk Üniversitesi Sosyal Bilimler Enstitüsü Dergisi, 20(2), 631-645.

Türkiye Sermaye Piyasaları Birliği (2016). Yıllık Yayınlar, Türkiye Sermaye Piyasası Raporu 2016, https://www.tspb.org.tr/tr/yillik-yayinlar/ (Erişim Tarihi: 18.10.2018).

Yapraklı, S., \& Güngör, B. (2007). Ülke riskinin hisse senedi fiyatlarına etkisi: IMKB 100 Endeksi üzerine bir araştırma. Ankara Üniversitesi SBS Dergisi, 62(2), 199-218. 